\title{
Aspects of the epidemiology of human Listeria monocytogenes infections in Britain 1967-1984; the use of serotyping and phage typing
}

\author{
J. MCLAUCHLIN, A. AUDURIER* and A. G. TAYLOR
}

Division of Microbiological Reagents and Quality Control, Central Public Health Laboratory, Colindale Avenue, London NW9 5HT, and * Laboratoire de Microbiologie, Faculté de Médecine, Hôpital Trousseau, 37032 Tours Cedex, France

\begin{abstract}
Summary. Strains of Listeria monocytogenes from 475 cases of human listeriosis collected during 1967-1984, belonged to one of three serogroups (1/2, 3 or 4$)$. They were phage typed with a set of 28 phages to investigate three aspects of the epidemiology of listeriosis. (i) Three patients each had two episodes of listeriosis, 3 months to 2 years apart, with strains of the same serogroup and indistinguishable by phage typing. (ii) Ten episodes of possible cross-infection between pairs of neonates in the same hospital occurred; the first baby was ill at or within 1 day of birth, and the second baby became ill 8-12 days after contact with the first. In each pair the L. monocytogenes strains were of the same serogroup and indistinguishable by phage typing. (iii) In three clusters of cases there may have been a common source of infection. L. monocytogenes strains from 10 of 11 cases of listeriosis in the Carlisle area in Jul.-Dec. 1981 were of the same serogroup; nine strains were non-phage-typable. The second cluster involved four adults treated at one hospital and the third a pair of neonates who were ill shortly after birth. In each cluster, strains were of the same serogroup, and were indistinguishable by phage typing. These last two clusters occurred during a short period when an unusually high proportion of strains from all cases of human listeriosis in Britain were indistinguishable by phage typing from the cluster strains, suggesting the possibility of common source infection.
\end{abstract}

\section{Introduction}

Listeria monocytogenes is a gram-positive bacillus first described in England causing a disease characterised by a mononuclear leukocytosis in laboratory animals (Murray et al., 1926). In 1929, Nyfeldt, in Denmark, isolated the same organism from infectious mononucleosis-like infections in man (Gray and Killinger, 1966). Burn (1936), in the USA, established L. monocytogenes to be a cause of infection in man during the perinatal period, and also described meningitis as a form of listeriosis in adults. However Dumont and Cotoni (Cotoni, 1942) had isolated a "diphtheroid" organism from the cerebro-spinal fluid of a soldier in France in 1919 that was held in the culture collection of the Pasteur Institute (Paris) for $>20$ years before it was identified as L. monocytogenes.

It is now clear that $L$. monocytogenes causes a wide range of disease in man; this includes meningo-encephalitis, septicaemia, pneumonia,

Received 12 Nov. 1985; revised version accepted 9 May 1986. endocarditis, localised abscesses, cutaneous lesions, conjunctivitis, urethritis, an infectious mononucleosis-like syndrome (Gray and Killinger, 1966), hepatitis (Yu et al., 1982; Hardie and Roberts, 1984) and arthritis (Newman et al., 1979).

In the perinatal period, listeriosis is most commonly an intra-uterine infection but can also present after the first week of life, frequently as meningitis. A pregnant woman who develops listeriosis may have a low grade septicaemia that appears clinically as an influenza-like illness in the later stages of the pregnancy. Trans-placental infection of the fetus may result in premature delivery of a stillborn or acutely ill infant with disseminated abscesses in the viscera (granulomatosis infantiseptica) and in the placenta. In less severe infections abscesses may be present in the lungs, digestive tract, skin and eyes but not in the placenta (Seeliger, 1961; Gray and Killinger, 1966).

In adults, meningo-encephalitis and bacteraemia are the commonest clinical findings (Nieman and Lorber, 1980), and although listeriosis may occur in apparently healthy individuals (Hone et al., 
Table I. Summary of three patients, each with two episodes of listeriosis

\begin{tabular}{|c|c|c|c|c|c|c|c|}
\hline \multirow[b]{2}{*}{ Patient } & \multirow[b]{2}{*}{ Age } & \multirow[b]{2}{*}{ Sex } & \multirow{2}{*}{$\begin{array}{l}\text { Other medical } \\
\text { condition }\end{array}$} & \multirow{2}{*}{$\begin{array}{l}\text { Clinical type } \\
\text { of listeriosis }\end{array}$} & \multirow{2}{*}{$\begin{array}{l}\text { Date of onset } \\
\text { of illness }\end{array}$} & \multicolumn{2}{|c|}{ L. monocytogenes } \\
\hline & & & & & & Serogroup & phage type* \\
\hline A & 8 & $\mathbf{M}$ & $\begin{array}{l}\text { Acute lymphoid } \\
\text { leukaemia }\end{array}$ & $\begin{array}{l}\text { Bacteraemia } \\
\text { Bacteraemia }\end{array}$ & $\begin{array}{l}\text { Jun. } 1984 \\
\text { Sep. } 1984\end{array}$ & $\begin{array}{l}1 / 2 \\
1 / 2\end{array}$ & $\begin{array}{l}3,6 \\
3,6\end{array}$ \\
\hline B & 38 & $\mathrm{~F}$ & Hodgkin's disease & $\begin{array}{l}\text { Bacteraemia } \\
\text { Pneumonia and meningitis }\end{array}$ & $\begin{array}{l}\text { Sep. } 1976 \\
\text { Nov. } 1977\end{array}$ & $\begin{array}{l}4 \\
4\end{array}$ & $\begin{array}{l}11 \\
11\end{array}$ \\
\hline $\mathrm{C}$ & NK & $\mathrm{F}$ & Renal transplant & $\begin{array}{l}\text { Bacteraemia } \\
\text { Bacteraemia }\end{array}$ & $\begin{array}{l}1968 \\
1970\end{array}$ & $\begin{array}{l}4 \\
4\end{array}$ & $\begin{array}{l}\text { NT } \\
11\end{array}$ \\
\hline
\end{tabular}

NK = not known.

NT $=$ not phage-typable.

* Phages that gave strong $(++)$ lytic reactions with strains. (For designation of phages see McLauchlin et al. (1986).)

1972; Howard et al., 1981), most patients are elderly or have predisposing factors such as malignant disease or immunodeficiency (Pollock et al., 1984). Because L. monocytogenes is an opportunist pathogen, whenever a "new" disease or treatment is described which predisposes an individual to infection, reports of listeriosis soon follow, e.g., in the acquired immune deficiency syndrome (Wetli et al.. 1983; Real et al.. 1984; Read et al., 1985) and in continuous ambulatory peritoneal dialysis (Myers et al., 1983). Seeliger (1972), on the basis of accidental laboratory infections, described L. monocytogenes as a "relatively mild pathogen for the healthy adult". The extent to which subclinical infection occur is speculative.

The epidemiology of listeriosis in man remains obscure. In this paper we present evidence about certain aspects of that epidemiology with particular reference to possible means of transmission.

\section{Materials and methods}

A phage-typing study was performed with 807 cultures of $L$. monocytogenes isolated from 479 cases of human listeriosis in the UK during 1967-1984 and collected at The Central Public Health Laboratory, Colindale. Strains were confirmed as $L$. monocvtogenes by the criteria of Seeliger and Höhne (1979) and Rocourt et al. (1983). and serotyped by the method of Seeliger and Höhne (1979) as serogroup 1/2 (O Factor I), serogroup 3 (O Factor IV), or serogroup 4 (O Factor V/VI).

Subcultures were sent to Tours under code in batches of about 50 strains over a period of 3 years for phage typing as described by Audurier et al. (1977 and 1979). Results were returned to Colindale for decoding and analysis. Strains were defined as distinguishable if there were $>1$ major phage-reaction differences for serogroup-1/2 strains, or $>2$ major differences for serogroup-4 (McLauchlin et al.. 1986).

\section{Results}

\section{Recurrent episodes of disease}

Strains of L. monocytogenes were received from three patients in each of whom two episodes of listeriosis had occurred. The periods between the pairs of episodes were 3 months to 2 years. The results of phage typing and serotyping are shown in table I, which also includes a brief clinical history of each patient. All had predisposing conditions and patient $B$ died from the second episode of listeriosis. The two strains of each pair of isolates were of the same serogroup and were indistinguishable by phage typing. (Because of the limits of reproducibility of the system, the single phagereaction difference between the strains from patient $C$ does not indicate that the strains were distinguishable).

\section{Hospital cross-infection amongst neonates}

During the period 1967-1984, strains of $L$. monocytogenes were received from 10 pairs of neonates in whom hospital cross-infection was suspected because the infections occurred in the same hospitals within short periods of time. Four of these incidents have been described (Campbell et al. 1981; Isaacs and Liberman, 1981; Sinha et al., 1983: Shrestha TL, Sunderland District General Hospital, personal communication).

Information was not available about two incidents, but in the other eight there was a common pattern: the first baby (baby 1) had congenital listeriosis clinically evident at or within 1 day of birth, and the second baby (baby 2) became ill (usually 8 12 days post partum) after direct or indirect contact 
Table II. Clinical summary of 10 pairs of neonates involved in episodes of hospital cross-infection by L. monocytogenes

\begin{tabular}{|c|c|c|}
\hline Clinical features & $\begin{array}{c}\text { Baby } 1 \\
\text { (ill at birth) }\end{array}$ & $\begin{array}{c}\text { Baby } 2 \\
\text { (apparently healthy } \\
\text { at birth) }\end{array}$ \\
\hline $\begin{array}{l}\text { Onset of symptoms } \\
\text { (post partum) }\end{array}$ & $\begin{array}{l}8 \text { within } 1 \text { day } \\
2 \mathrm{NK}\end{array}$ & $\begin{array}{l}1 \text { on day } 3 \\
1 \text { on day } 4 \\
6 \text { on days } 8-12 \\
2 \text { NK }\end{array}$ \\
\hline Symptoms & $\begin{array}{l}5 \text { respiratory } \\
\text { distress } \\
3 \text { septicaemia } \\
2 \text { meningitis }\end{array}$ & $\begin{array}{l}8 \text { meningitis } \\
1 \text { respiratory distress } \\
1 \text { pyrexia, fits and } \\
\text { jaundice }\end{array}$ \\
\hline $\begin{array}{l}\text { Duration of } \\
\text { pregnancy }\end{array}$ & $\begin{array}{l}130 \text { weeks } \\
131 \text { weeks } \\
133 \text { weeks } \\
134 \text { weeks } \\
138 \text { weeks } \\
2 \text { term ( } 40 \text { weeks) } \\
3 \mathrm{NK}\end{array}$ & $\begin{array}{l}135 \text { weeks } \\
136 \text { weeks } \\
137 \text { weeks } \\
138 \text { weeks } \\
139 \text { weeks } \\
2 \text { term }(40 \text { weeks }) \\
3 \mathrm{NK}\end{array}$ \\
\hline Caesarian section & 3 & 2 \\
\hline Fatal outcome & $2(2 \mathrm{NK})$ & $0(2 \mathrm{NK})$ \\
\hline $\begin{array}{l}\text { Illness in mother } \\
\text { during pregnancy }\end{array}$ & $\begin{array}{l}5 \text { pyrexial 'flu } \\
\text {-like' illness }\end{array}$ & $\begin{array}{l}1 \text { mild cold } \\
1 \text { laryngitis }\end{array}$ \\
\hline $\begin{array}{l}\text { L. monocytogenes } \\
\text { isolated from } \\
\text { HVS of mother }\end{array}$ & 4 & 0 \\
\hline
\end{tabular}

$\mathrm{NK}=$ not known; HVS $=$ high vaginal swab.

with baby 1 . A summary of clinical information about these incidents is shown in table II. Crossinfection was deduced by finding that strains isolated from the pairs of babies were always of the same serogroup (two pairs yielded strains of serogroup $1 / 2$, and the other eight pairs of strains were of serogroup 4), and that each pair was indistinguishable by phage typing (table III) except in one episode from which one of the strains was not available for examination. Cross-infection was also suggested in four of the pairs of cases by the detection of anti-Listeria antibodies in the serum of the mother of baby 1 but not in the serum from the mother of baby 2 (McLauchlin and Taylor, unpublished results).

Possible modes of transmission were suggested in nine of the episodes (no information was available about one). In one episode "contact" between the two neonates was specified. In seven others the neonates were either delivered and nursed in the same room, or attended by the same obstetric staff
Table III. Serogroups and phage types of strains involved in cross-infection between neonates

\begin{tabular}{|c|c|c|}
\hline & Serogroup & Phage type \\
\hline \multicolumn{3}{|l|}{ Episode 1} \\
\hline Baby 1 & 4 & $10,12,14$ \\
\hline Baby 2 & 4 & not tested \\
\hline \multicolumn{3}{|l|}{ Episode 2} \\
\hline Baby 1 & 4 & $11,(12)$ \\
\hline Baby 2 & 4 & 11 \\
\hline \multicolumn{3}{|l|}{ Episode 3} \\
\hline Baby 1 & $1 / 2$ & 1,3 \\
\hline Baby 2 & $1 / 2$ & 1,3 \\
\hline \multicolumn{3}{|l|}{ Episode 4} \\
\hline Baby 1 & 4 & $(8), 10,13,24,27$ \\
\hline Baby 2 & 4 & $(8),(10), 13,((24)), 27$ \\
\hline \multicolumn{3}{|l|}{ Episode 5} \\
\hline Baby 1 & 4 & $(8), 10,12,14$ \\
\hline Baby 2 & 4 & $(8), 10,12,14$ \\
\hline \multicolumn{3}{|l|}{ Episode 6} \\
\hline Baby 1 & $1 / 2$ & $(2), 4$ \\
\hline Baby 2 & $1 / 2$ & $(2), 4$ \\
\hline \multicolumn{3}{|l|}{ Episode 7} \\
\hline Baby 1 & 4 & 20,27 \\
\hline Baby 2 & 4 & 20,27 \\
\hline \multicolumn{3}{|l|}{ Episode 8} \\
\hline Baby 1 & 4 & $8,9,11,13,15$ \\
\hline Baby 2 & 4 & $8,9,11,13,15$ \\
\hline \multicolumn{3}{|l|}{ Episode 9} \\
\hline Baby 1 & 4 & $8,10,12,14,27$ \\
\hline Baby 2 & 4 & $8,10,12,14,27$ \\
\hline \multicolumn{3}{|l|}{ Episode 10} \\
\hline Baby 1 & 4 & $8,9,11,((12)), 13,15,19$ \\
\hline Baby 2 & 4 & $8,9,11,13,15,19$ \\
\hline
\end{tabular}

( ) phages that gave moderate lytic reactions; (( )) phages that gave weak lytic reactions.

or delivered with the same obstetric equipment. In the final case there was contact between baby 2 and the mother of baby 1 when both mothers and baby 2 were nursed in adjacent beds in an open ward (Isaacs and Liberman, 1981).

\section{Common source infection in hospital or community}

(a) Common source of listeriosis in East Cumbria. During the period Jul.-Dec. 1981, 11 cases of listeriosis in Carlisle and the surrounding area were diagnosed by bacterial isolation (S. Hall, CDSC Colindale, personal communication). Four were perinatal infections and all four infants were either still-born or died within $24 \mathrm{~h}$ of birth. The other seven patients were adults, one of whom died. All the adults had signs of meningitis and only one had a severe underlying disease (Hodgkin's lymphoma). Ten of the strains were available for typing-all were serogroup $1 / 2$, and nine were nonphage-typable. 


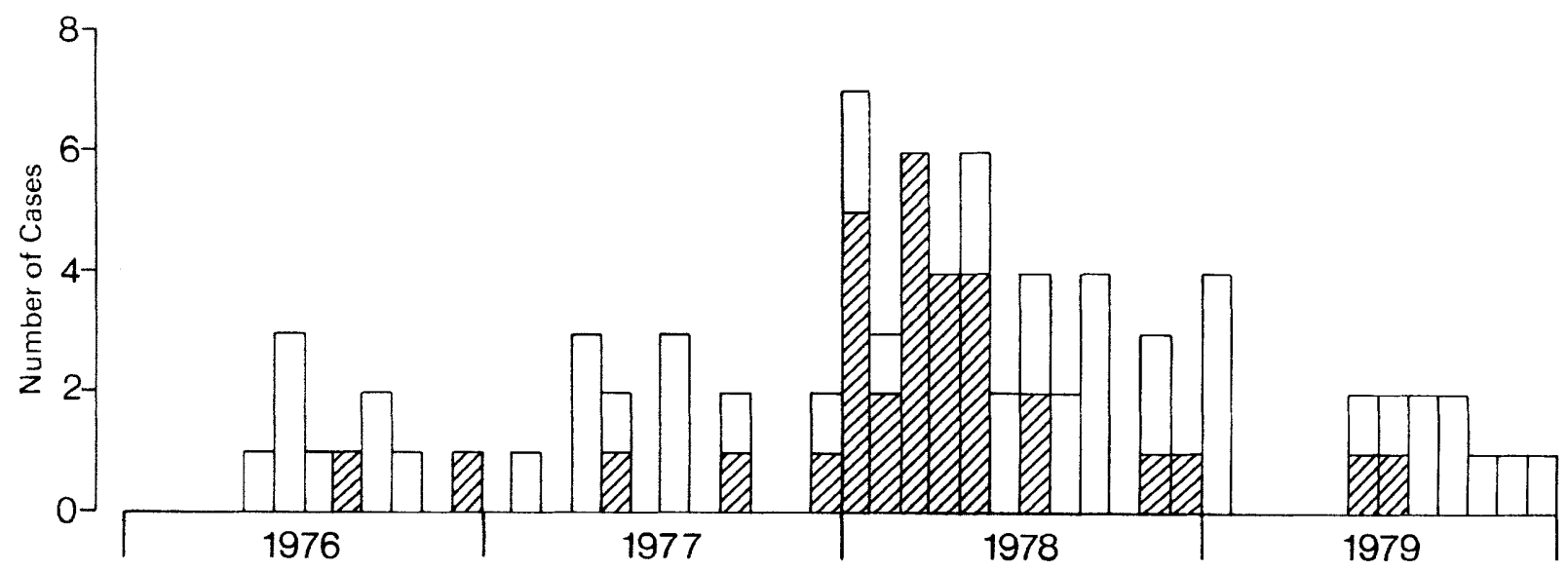

Fig. 1. Monthly occurrence of cases of listeriosis caused by serogroup 4 in Britain 1976 1979; 7 strains indistinguishable by phage typing from strains isolated in Liverpool outbreak (Green and Macaulay, 1978); $\square$ strains of other phage types.

(b) Common source or cross-infection episodes in hospitals and clusters of cases in the community. It was noted that many cases of listeriosis that occurred over relatively short periods were caused by strains indistinguishable by phage typing. In the following two clusters of cases, $>55 \%$ of the $L$. monocytogenes serogroup-4 strains isolated in Britain during a 6-month period were indistinguishable by phage typing.

CLUSTER 1. We (Taylor et al., 1981) previously described phage typing of strains from four cases of listeriosis caused by serogroup- 4 strains in the same Liverpool hospital during a 2-month period (Feb.-Apr. 1978) in which there could have been case-tocase transmission or a common source for the outbreak (Green and Macaulay, 1978). We then reported that the strain isolated from one of the four cases was probably different in origin from the other three, but on completion of phage-typing reproducibility studies (McLauchlin et al., 1986) this strain was indistinguishable from the isolates from the other three cases. Furthermore, retesting this strain yielded an almost identical phage-lysis pattern to that of the strains isolated from the other three cases. During the period (Dec. 1977-Jul. 1978) 24 out of $34(70 \%)$ of the serogroup- 4 strains sent from cases of listeriosis in Britain were indistinguishable by phage typing from the Liverpool isolates described above. The proportion of listeriosis cases due to these "Liverpool type" serogroup-4 strains in the period 1976-1979 is shown in fig. 1, and the distribution by Regional Health Authority of this "type" during the period Dec. 1977 Jul, 1978 is shown in fig. 2.

CLUSTER 2. A pair of cases of perinatal listeriosis occurred that was similar to those already described except that cross-infection was not thought to have taken place. The two cases occurred within $48 \mathrm{~h}$ in Oct. 1983 in the same hospital in the North West Thames Regional Health Authority, and $L$. monocytogenes serogroup 4 was isolated from both neonates. Each was ill within $24 \mathrm{~h}$ of birth. $L$. monocytogenes of the same serogroup was also isolated from both mothers (table IV). The four strains were indistinguishable by phage typing. Common source infection was further supported by the presence of anti-Listeria antibodies in sera from both mothers (McLauchlin and Taylor, unpublished observation). However, during the period Aug.-Dec. 1983 when this pair of cases occurred, strains from $23(56 \%)$ out of the 41 cases of listeriosis due to serogroup-4 strains received at Colindale from UK hospitals were indistinguishable by phage typing from the strains isolated from this pair of cases. The proportion of cases due to these serogroup- 4 strains in the preceding 3 years is shown in fig. 3, and their distribution by Regional Health Authority during Aug.--Dec. 1983 is shown in fig. 4 .

\section{Discussion}

\section{Recurrent episodes}

There appear to be at least four possible explanations for the epidemiology of listeriosis when patients are affected by recurrent episodes of the disease - (i) chance re-infection by different strains; (ii) re-infection by different strains because of a genetic predisposition to the disease; (iii) reinfection from the same or similar environmental source; or (iv) incomplete eradication of the original infection, persistence of the strain and subsequent recrudescence of infection. Listeriosis may 

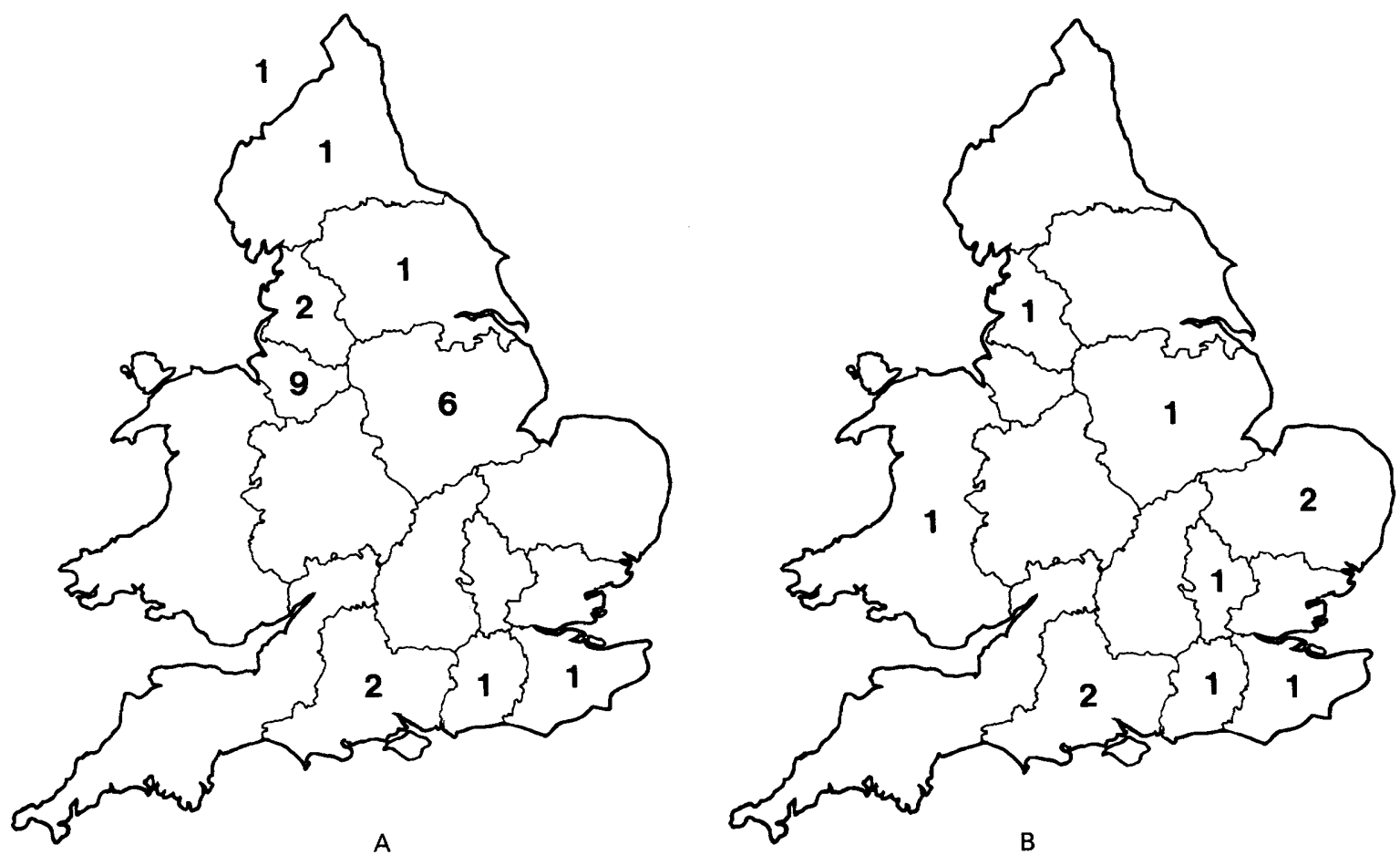

Fig. 2. Distribution of cases of listeriosis caused by serogroup-4 strains by Regional Health Authority, Dec. 1977-Jul. 1978. A. Strains indistinguishable by phage typing from strains isolated in the Liverpool outbreak (Green and Macaulay, 1978). B. Strains of other phage types.

Table IV. Common source outbreak of perinatal listeriosis

\section{Case $1 \quad$ Case 2}

Date of birth

and onset of

symptoms $\quad 28 / 10 / 83 \quad 30 / 10 / 83$

L. monocytogenes

serogroup-4 isolated from:

$\begin{array}{cc}\text { baby } & \text { Gastric aspirate and } \\ \text { eye } & \text { and rectal swab }\end{array}$

mother Blood culture HVS

Phage type* $\quad 8,9,11,13,15,28 \quad 8,9,11,13,15,28$

HVS $=$ high vaginal swab.

* Strong $(++)$ lytic reactions only.

be much commoner and have a wider spectrum of severity than is generally realised so that subclinical forms are largely undiagnosed and unreported. All three patients with two episodes were immunosuppressed and, as well as being investigated more intensively, they may have suffered more severe illness than previously healthy individuals. However, because the incidence of listeriosis even in patients with serious underlying disease is low, it seems unlikely that recurrent episodes caused by indistinguishable strains could be due to chance alone.

Genetic factors appear to be important in the pathogenesis of infection with mycobacteria in man (Van Eden et al., 1983). Like L. monocytogenes, these are intracellular pathogens and similar pathogenic and host defence mechanisms may be involved. Genetically inbred lines of mice show differences in susceptibility to listeria infection and in inflammatory responses (Skamene, 1983), but whether there are analogous effects in man is not known. Three reports (Becroft et al., 1971; Lennon et al., 1984; Canfield et al., 1985) describe outbreaks in New Zealand and the USA in which higher than expected proportions of particular ethnic groups were infected. However these authors did not discuss the possibility of genetic predisposition but suggested that diet and socioeconomic factors may have been important. The finding that in each of our patients the first and second isolates were of the same serogroup and were indistinguishable by phage typing provides strong evidence that these recurrent episodes were not caused by different strains and therefore the first and second explanations would seem unlikely.

Re-infection from the same or a similar source 


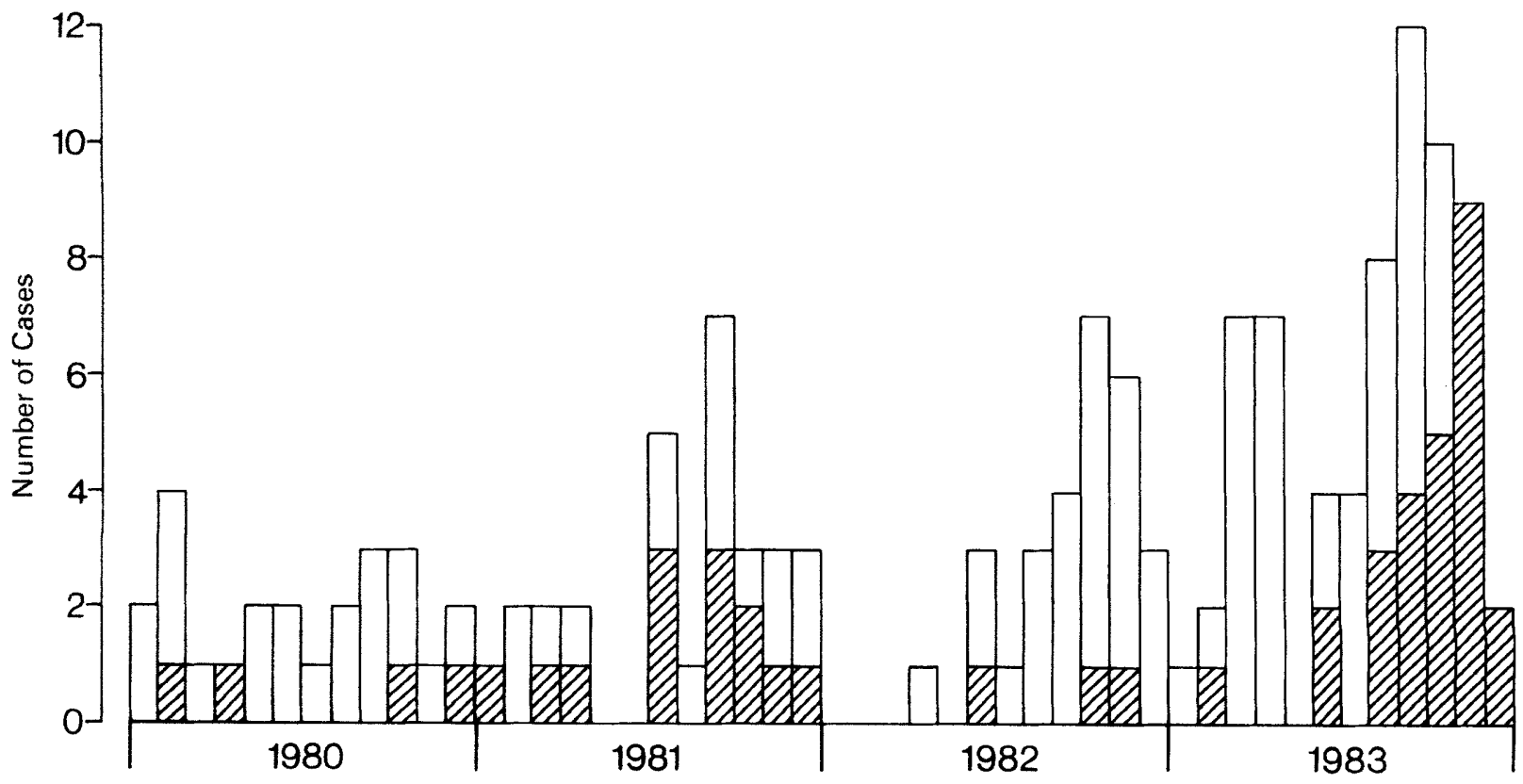

Fig. 3. Monthly occurrence of cases of listeriosis caused by serogroup-4 strains in Britain 1980 1983; $\square$ strains indistinguishable by phage typing from strains isolated in cases described in table IV; $\square$ strains of other phage types.

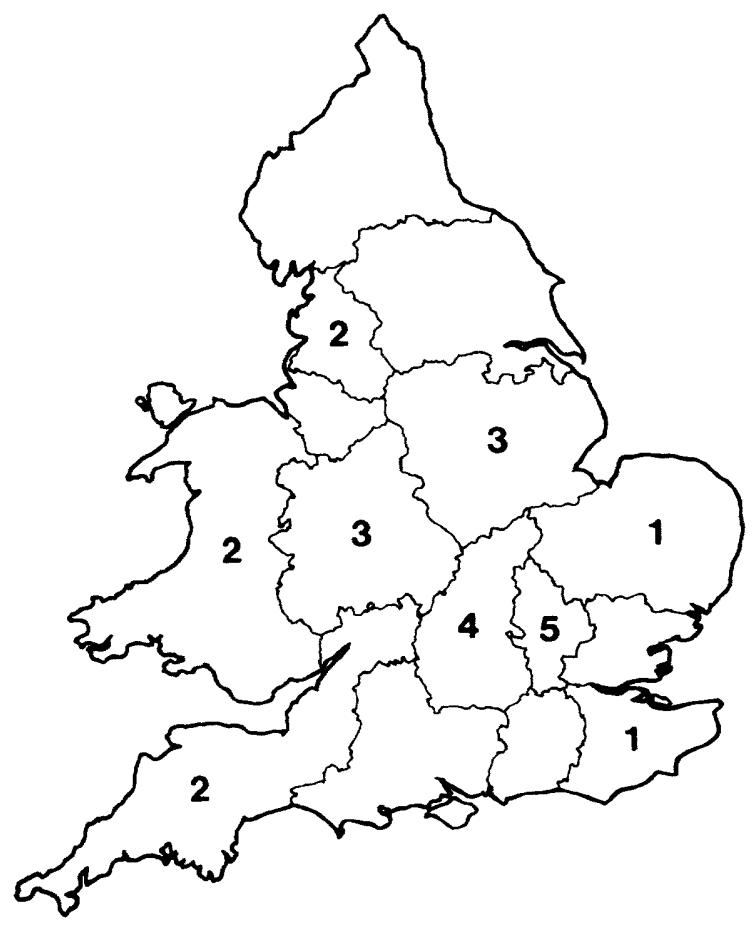

A

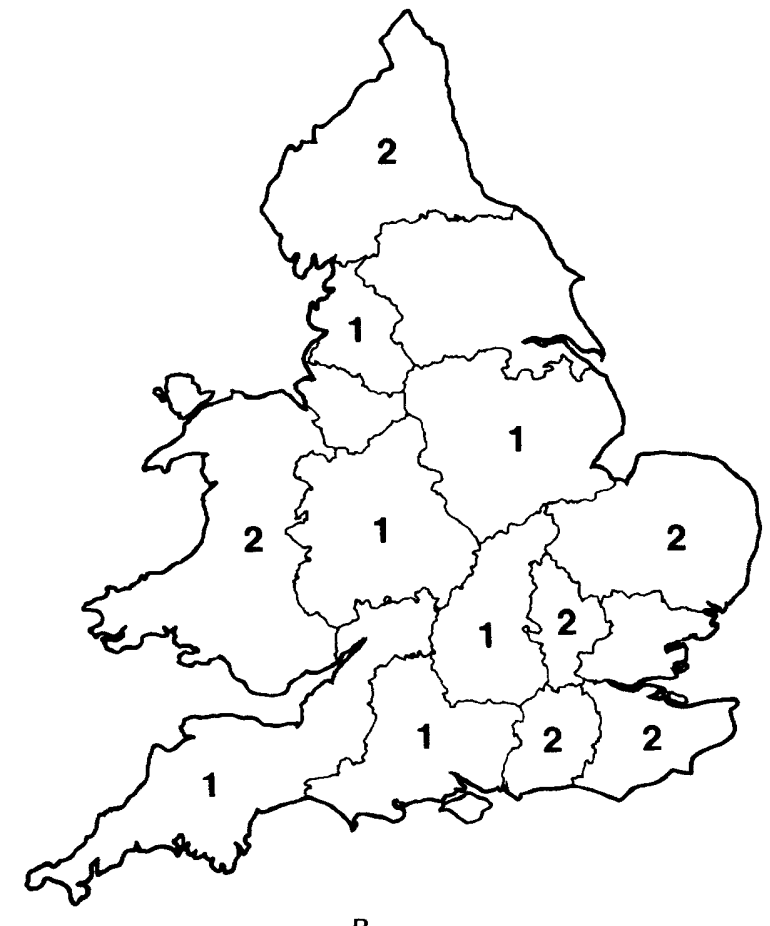

B

Fig. 4. Distribution of cases of listeriosis caused by serogroup-4 strains by Regional Health Authority, Aug.-Dec. 1983. A. Strains indistinguishable by phage typing from strains isolated in cases described in table IV. B. Strains of other phage types. 
could involve direct or indirect contact with animals or animal products, and infections in veterinarians from exposure to infected animals have been reported (Owen et al., 1960; Seeliger, 1961). A wide range of animals may be infected by $L$. monocytogenes or may carry and excrete it in high numbers without apparent illness (Gray and Killinger, 1966). In Britain animal listeriosis is commonest in sheep and cattle (Veterinary Record, 1983). Another possible source of infection could be the endogenous flora of the patient or of a household contact. Estimates of faecal carriage rates in healthy human individuals vary from 0.6 to $70 \%$ (Kampelmacher and van Noorle Jansen, 1972; Ralovich, 1984). Vaginal and pharyngeal carriage has also been reported (Gray and Killinger, 1966; Ralovich, 1984) but little is known about long term carriage. L. monocytogenes has been isolated from human semen (Toaff et al., 1962) and the possibility of sexual transmission as an explanation of re-infection cannot be ignored. The association of listeriosis with iatrogenic immunosuppression in, for example, renal transplant patients (Isiadinso, 1975; Nieman and Lorber, 1980) further indicates that autochthonous infection occurs.

Three further possible environmental sources of L. monocytogenes could be soil, animal excreta (Seeliger, 1961) or food. The possibility of food borne infection is discussed below; certain foods have been implicated with the transmission of $L$. monocytogenes to man (Schlech et al., 1983; Fleming et al., 1985) and an individual's dietary habits may lead to re-infection.

$L$. monocytogenes is a facultative intracellular parasite (Mackaness, 1971) and the fourth possibility of incomplete eradication and survival in the host at sites other than the gut, respiratory tract or genital tract cannot be excluded.

Although listeriosis has been reported to cause recurrent abortion (Gray and Killinger, 1966), this is probably rare. Of the 187 cases of perinatal listeriosis from which strains were sent to DMRQC between 1967 and 1984, none of the mothers were known to have had bacteriologically confirmed listeriosis on more than one occasion. However, the occurrence of three non-perinatal cases of multiple episodes of listeriosis, of which there is only one similar report (Bodey et al., 1968), suggests that reinfection, chronic infection or long term carriage of L. monocytogenes may occur, and that recurrent abortion due to listeriosis is possible.

\section{Cross-infection}

We have presented the largest series of cases with strong evidence of cross-infection with $L$. monocytogenes from congenitally infected newborn infants to apparently healthy neonates in hospital. These cases highlight some of the characteristics of listeriosis in neonates (Gray and Killinger, 1966; Seeliger and Finger, 1983). Early onset disease (baby 1 ) is characterised by septicaemia and respiratory distress, and late onset disease (baby 2) by meningitis. This difference may be related to the developmental stage of the fetus or neonate and the route of infection. Similar differences are found in other bacterial infections of the newborn, e.g., those due to Lancefield group-B streptococci (Parker, 1979). L. monocytogenes can be isolated from the genital tracts of mothers of babies with early onset listeriosis; the mothers may also develop a mild pyrexial illness during pregnancy or at delivery. In this series, L. monocytogenes was isolated from four mothers of the early onset cases; five mothers developed a pyrexial "flu-like" illness. However, the number of mothers from whom culture was attempted is not known. It is interesting that six of the ten neonates with late onset disease either were born by caesarian section or were premature, and may therefore have been especially susceptible to infection.

Several reports describe similar cases of crossinfection amongst perinates (Burn, 1936; Line and Cherry, 1952; Mencikova, 1956; Levy and Nassau, 1960; Dubois and Lefebvre, 1965; Joppich and Schulte, 1968; Becroft et al., 1971; Humbert et al., 1976; Larsson et al., 1978; Laugier et al., 1978; Dickgiesser, 1980; Kachel and Lenard, 1981; King et al., 1982). In one of these, Larsson et al. (1978) suggested that infection was spread from one neonate to four others by common use of a rectal thermometer.

Although listeriosis in the perinate is relatively rare, hospital cross-infection in the UK is more common than is generally realised. During 19671984 we received strains from 187 cases of perinatal listeriosis of which 20 were associated with crossinfection (i.e., 1 in 9.4 cases). Dickgiesser (1980) reported that $L$. monocytogenes could survive well in the environment (20-30 days on dry tiled surfaces and 10 days in tap water) and suggested that clinicians should be informed of the relative numbers of cases that lead to cross-infection and the need for barrier nursing of neonates with listeriosis. 
Table V. Common source outbreaks of listeriosis

\begin{tabular}{|c|c|c|c|c|c|c|c|}
\hline \multirow[b]{2}{*}{ Place } & \multirow[b]{2}{*}{ Time of outbreak } & \multicolumn{3}{|c|}{ Number of cases } & \multirow{2}{*}{\multicolumn{2}{|c|}{$\begin{array}{c}\text { Suggested } \\
\text { agents of } \\
\text { p transmission }\end{array}$}} & \multirow[b]{2}{*}{ Reference } \\
\hline & & Total & Adults & Perinates & & & \\
\hline Prague, Czechoslovakia & Aug. Nov. 1955 & 41 & 0 & $4 !$ & $1 / 2$ & NK & Mencikova, 1956 \\
\hline Bremen. Germany & NS $1960-196 I$ & 81 & NS & NS & NS & NK & Seeliger et al., 1969 \\
\hline Bremen, Germany & NS 1963 & 20 & NS & NS & NS & NK & Seeliger et al., 1969 \\
\hline Halle, Germany & Apr.-Dec. 1966 & 279 & 0 & 279 & $1 / 2$ & NK & Ortel, 1968 \\
\hline Auckland, New Zealand & Apr. Sep. 1969 & 20 & 6 & 14 & NS & NK & Flight, 1971 \\
\hline Greenville, USA & Mar.-Oct. 1975 & 6 & 0 & 6 & $4 b$ & NK & Filice et al., 1978 \\
\hline Anjou. France & Jan. Jun. 1976 & 162 & 36 & 126 & $4 b$ & NK & Carbonnelle et al., 1979 \\
\hline Perth, Australia & Jan.-Mar. 1978 & 4 & 0 & 4 & NS & NK & Le Souef and Walters, 1981 \\
\hline Perth, Australia & Jan.-Mar. 1979 & 6 & 0 & 6 & NS & NK & Le Souef and Walters, 1981 \\
\hline Auckland. New Zealand & Jan.-Jun. 1980 & 21 & 3 & 18 & $1 / 2 \mathrm{a}$ & Seafood? & Lennon et al., 1984 \\
\hline Nova Scotia. Canada & Apr.-Sep. 1981 & 41 & 7 & 34 & $4 b$ & Coleslaw & Schlech et al., 1983 \\
\hline Houston, USA & May.-Jul. 1983 & 10 & 0 & 10 & $1 / 2 b$ & NK & Canfield et al., 1985 \\
\hline Massachusetts. USA & Jun.-Aug. 1983 & 49 & 42 & 7 & $4 b$ & Milk & Fleming et al., 1985 \\
\hline Lausanne, Switzerland & Jan. 1983-Mar. 1984 & 25 & 14 & 11 & $4 b$ & NK & Malinverni et al., 1985 \\
\hline
\end{tabular}

$\mathrm{NK}=$ not $\mathrm{known}: \mathrm{NS}=$ not stated.

\section{Common source infections}

(a) East Cumbria outbreak. Such a large number of cases in a 6-month period was not seen in the area served by the Carlisle Public Health Laboratory either before or after this cluster of strains (D. G. Davies, Carlisle Public Health Laboratory, personal communication) even though a particular interest in the organism developed. The large cluster of cases in a short time suggested a common source outbreak; the results of our serotyping and phage typing of the isolates are consistent with but do not prove this view. A mode of transmission was not established for this outbreak (S. Hall, CDSC Colindale, personal communication).

(b) Common source or cross-infection episodes in hospitals and clusters of cases in the community. The occurrence of listeriosis in four adults treated in a Liverpool hospital during a 2-month period (Green and Macaulay, 1978) in cluster 1 and the isolation of strains of indistinguishable phage type from each patient suggest a causal link. Either crossinfection took place as has been suggested (Green and Macaulay, 1978; Taylor et al., 1981) or these patients were infected from a common source. The mode of transmission of listeriosis to the pair of neonates in cluster 2 is clearly dissimilar to that already described for the 10 pairs of neonates in whom cross-infection was suspected. Although these two neonates were born in the same hospital within a short period of time and the isolates of $L$. monocytogenes from the babies were indistinguishable by phage typing, the isolation of indistinguishable strains from both mothers, who were also seropositive, suggests an epidemiological link other than cross-infection. They may have been infected from an unknown source (e.g., food), or crossinfection between the mothers may have occurred during pregnancy (possibly through obstetric examination). At the time when these two clusters of cases occurred a high proportion of the other cases caused by L. monocytogenes serogroup 4 were also indistinguishable by phage-typing from these strains, and the cases were restricted to a few Regional Health Authorities (especially in the case of cluster 1). Strains of these "epidemic" phage-types did not occur at high frequencies during preceding and following periods throughout Britain, nor in the Health Authorities where the clusters occurred in subsequent years (results not given).

These clusters may represent common source outbreaks. Several such outbreaks have been reported (table V); some affected more than 100 people, most notably those in Halle, East Germany (Ortel, 1968), and Anjou, France (Carbonnelle et al., 1979). In common with clusters 1 and 2 and the East Cumbria outbreak, these occurred during a period of several months, but otherwise had few common features. They occurred throughout the year (regardless in which hemisphere they took place), affected either mainly adults or mainly perinates or similar numbers of each, and involved either serogroup $1 / 2$ or 4 .

The mode of transmission of epidemic or sporadic listeriosis is largely unknown, although one possible vehicle for L. monocytogenes is food. It has long been realised (Gray, 1963) that there is an apparent relationship between silage feeding and listeriosis in ruminants, but a clear relationship between food and human listeriosis has only rarely 
been established and the extent to which food may be involved is unclear. Because $L$. monocytogenes grows and multiplies at $+4^{\circ} \mathrm{C}$, refrigerated food such as meat, eggs, poultry, vegetables and milk are implicated as potential sources of infection. Raw poultry (Kwantes and Isaac, 1975; Gitter, 1976) and red meat (Höhne et al., 1975; Elischerova et al., 1979 ) are frequently contaminated with $L$. monocytogenes, and the usual preserving agents such as sodium chloride and sodium nitrite inhibit the growth of this organism only slightly (Shahamat $e t$ al., 1980). L. monocytogenes causes mastitis in cows (Gitter et al., 1980) and large numbers of bacteria may be shed into milk. Burn (1936) suggested milk as a possible source of infection and Gray (1963) recalls that a woman who drank raw milk from a cow with mastitis subsequently gave premature birth to still-born twins infected with $L$. monocytogenes of the same serogroup as that isolated from the milk. Pasteurisation of milk may not completely eradicate $L$. monocytogenes when present in large numbers (Bearns and Girard, 1958) and in one recent outbreak (Fleming et al., 1985) milk was suggested to be the vehicle of infection. In another outbreak (Schlech et al., 1983), coleslaw salad was a possible source, and $L$. monocytogenes of the serotype implicated in the outbreak was grown from coleslaw from the refrigerator of one of the patients. The cabbage used in the coleslaw was from a farm where cases of ovine listeriosis had occurred. In both these clusters of cases phagetyping results were consistent with a common source food-borne outbreak (Audurier et al., 1984; Fleming et al., 1985).

The need for typing schemes of higher discrimination than those generally available is evident. We estimate the incidence of listeriosis in man in the UK to be at least 0.18 cases per $10^{5}$ of the total population per year. This figure represents the minimum incidence because it was calculated from the number of cases from which cultures were sent to DMRQC and does not include cases reported to the Communicable Disease Surveillance Centre Colindale without isolates being sent to DMRQC, or cases which were unreported to either centre.

\section{REFERENCES}

Audurier A, Rocourt J, Courtieu A L 1977 Isolement et caractérisation de bactériophages de Listeria monocytogenes. Annales de Microbiologie (Institut Pasteur) 128A:185-198.

Audurier A, Chatelain R, Chalons F, Piéchaud M 1979 Lysotypie de 823 souches de Listeria monocytogenes isolées en France de 1958 à 1978. Annales de Microbiologie (Institut Pasteur) 130B:179-189.
Table VI. Incidence of human listeriosis in northern Europe and North America (adapted from Ralovich, 1984)

\begin{tabular}{lc}
\hline Country & $\begin{array}{c}\text { Cases } / 10^{5} \text { total } \\
\text { population/year }\end{array}$ \\
\hline Germany (GDR) & $0 \cdot 336$ \\
France & 0.327 \\
Denmark & 0.227 \\
Switzerland & $0 \cdot 205$ \\
Netherlands & 0.169 \\
Sweden & $0 \cdot 148$ \\
Germany (FRG) & 0.096 \\
USA & 0.066 \\
Canada & 0.062 \\
\hline
\end{tabular}

Estimates for the incidence of listeriosis in North America and Northern Europe (table VI) show that the incidence is considerably higher in France and the UK than in the USA and Canada. In countries with lower incidence, outbreaks will be more obvious because of the lower background of individual cases, but in countries with a higher incidence cases related by source may be much more difficult to identify without highly discriminatory typing schemes.

Listeriosis in man is sporadic in nature and of low incidence; the route of transmission is usually impossible to determine. We have highlighted some possible routes of infection and presented data which support these epidemiological relationships. Although listeriosis is a disease common to animals and man there is rarely an obvious epidemiological relationship between them, and the disease is not considered to be principally a true zoonosis. $L$. monocytogenes occurs ubiquitously in man, animals and the environment, and has many of the characteristics of a saprophyte. It has even been suggested (Maupas et al., 1975) that listeriosis should be categorised as a "sapronis", i.e., a disease of "man and animals contaminated from a common origin constituted by the outer environment".

We acknowledge the help of Dr S. Hall, CDSC, Colindale.
Audurier A, Taylor A G, Carbonnelle B, McLauchlin J 1984 A phage typing system for Listeria monocytogenes and its use in epidemiological studies. Clinical and Investigative Medicine 7:229-232.

Bearns R E, Girard K F 1958 The effect of pasteurization on Listeria monocytogenes. Canadian Journal of Microbiology 4:55-61.

Becroft D M O et al., 1971 Epidemic listeriosis in the newborn. British Medical Journal 3:747-751. 
Bodey G P, Hersh E M, Freireich E J 1968 Recurrent Listeria monocytogenes meningitis in a patient with acute leukemia. Cancer 21:619-622.

Burn C G 1936 Clinical and pathological features of an infection caused by a new pathogen of the genus Listerella. American Journal of Patholog. 12:341 348.

Campbell A N. Sill P R, Wardle J K 1981 Listeria meningitis acquired by cross-infection in a delivery suite. Lancet 2: 752753 .

Canfield M A et al. 1985 An epidemic of perinatal listeriosis serotype $1 \mathrm{~b}$ in Hispanics in a Houston hospital. Pediatric Infectious Disease 4: 106.

Carbonnelle B et al. 1979 Epidemie de Listériose dans l'Ouest de la France (1975 1976). Revue Epidémiologie et de Santé Publique (Paris) 26:451 467.

Cotoni L 1942 A propos des bactéries dénommées Listerella rappel d'une observation ancienne de méningite chez Thomme. Annales de Institut Pasteur 68:92-95.

Dickgiesser N 1980 Listeria monocvtogenes als Ursache van Krankenhausinfektionen: Untersuchungen zum Uberleben der Erreger in der Aubenwelt. Infection 8:199-201.

Dubois $O$. Lefebvre C 1965 Aspects épidémiologiques des infections à Listeria monocytogenes chez le nouveau-né. Pediatrie 20:533 543 .

Elischerova K. Stupalova S. Stepanek J 1979 Some ecological aspects of Listeria monocytogenes in meat industry. In: Ivanov 1 (ed) Problems of listeriosis. Proceedings of the seventh international symposium. National Agroindustrial Union Center for Scientific Information, Sofia, pp 148-155.

Filice G A. Cantrell H F. Smith A B. Hayes P S. Feeley J C. Fraser D W 1978 Listeria monocytogenes infection in neonates: investigation of an epidemic. Journal of Infectious Diseases 138:17 23

Fleming D W et al. 1985 Pasteurized milk as a vehicle of infection in an outbreak of listeriosis. New England Journal of Medicine 312:404 407.

Flight R J 1971 Listeriosis in Auckland. Nen Zealand Medical Journal 73:349 351.

Gitter M 1976 Listeria monocytogenes in "oven-ready" poultry. Veterinary Record 99:336.

Gitter M. Bradley R. Blampied P H 1980 Listeria monocyogenes infections in bovine mastitis. Veterinary Record 107: $390-393$

Gray M L 1963 Epidemiological aspects of listeriosis. American Journal of Public Health 53:554 563.

Gray M L, Killinger A H 1966 Listeria monocylogenes and listeric infections. Bacteriological Reviews 30: 309--382.

Green H T. Macaulay M B 1978 Hospital outbreak of Listeria monocrtogenes septicaemia: a problem of cross-infection? Lance' 2:1039-1040.

Hardie R. Roberts W 1984 Adult listeriosis presenting as acute hepatitis. Journal of Infection 8:256 258.

Höhne K. Loose B. Seeliger H P R 1975 lsolation of L. monocltogenes in slaughter animals and bats in Togo (West Africa). Annales de Microbiologie (Institut Pasteur) 126A:501-507.

Hone R. Marshall P. Cran H 1972 Listeria monocltogenes meningitis in a healthy adult. Journal of the Irish Medical Assoriation 65:81 82 .

Howard A J. Kennard C. Eykyn S. Higgs I 1981 Listerial infections of the central nervous system in the previously healthy adult. Infection 9:80-84.

Humbert G. Duval C. Fessard C. Meunier M. Ledoux A 1976 Les Listérioses en France. Résultats dune enquête National (824 cas.). Medécine et Maladies Infectieuses 6 Suppl:60 69

Isaacs D. Liberman M M 1981 Babies cross-infected with Listeria monocitogenes. Lancet 2:940.
Isiadinso O A 1975 Listeria sepsis and meningitis: a complication of renal transplantation. Journal of the American Medical Association 234:842-843.

Joppich G. Schulte F J 1968 Neurologie des Neugeboren. Springer. Berlin. pp 412-423.

Kampelmacher E H, van Noorle Jansen L M 1972 Further studies on the isolation of $L$. monocytogenes in clinically healthy individuals. Zentralblatt für Bakteriologie, Parasitenkunde. Infektionskrankheiten und Hygiene. I Abteilung Originale A. 221:70 77 .

Kachel W. Lenard H G 1981 Babies cross-infected with Listeria monocytogenes. Lancet 3:939-940.

King H S. Duncan J, Tracey P M 1982 Nosocomial transmission of listeriosis? Canadian Medical Association Journal 126:1374.

Kwantes W, Isaac M 1975 Listeria infection in West Glamorgan. In: Woodbine M (ed) Problems of listeriosis, Proceedings of the sixth international symposium. Leicester University Press, pp 112-114.

Larsson S, Cederberg A, Ivarsson S, Svanberg L, Cronberg S 1978 Listeria monocytogenes causing hospital-acquired enterocolitis and meningitis in newborn infants. British Medical Journal 2:473 474.

Laugier J. Borderon J C, Chantepie A, Tabarly J L, Gold F 1978 Meningite du nouveau-né a Listeria monocytogenes et contamination en maternité. Archives Françaises de Pédiatrie 35:168-171.

Lennon D et al. 1984 Epidemic perinatal listeriosis. Pediatric Infectious Disease 3:30 34

Le Souef P N. Walters B N J 1981 Neonatal listeriosis a summer outbreak. Medical Journal of Australia 2:188-191.

Levy E. Nassau E 1960 Experience with listeriosis in the newborn. An account of a small epidemic in a nursery ward. Annales Paediatrici 194:321 330.

Line F G, Cherry W B 1952 Meningitis due to Listeria monocytogenes; report of 2 cases. Journal of the American Medical Association 148:366-369.

Mackaness G B 1971 Resistance to intracellular infection. Journal of Infectious Diseases 123:439 445.

Malinverni R, Bille J, Perret C, Regli F, Tanner F, Glauser M P 1985 Listériose epidémique: observation de 25 cas en 15 mois au Centre hospitalier Universitaire Vaudois. Schweizerische Medizinische Wochenshcrift 115:2-10.

Maupas Ph. Bind J L, Chiron J P, Darchis J P 1975 Epidemiologic and pathogenic conception of animal and human listeriosis. In: Woodbine $M$ (ed) Problems of listeriosis. Proceedings of the sixth international symposium. Leicester University Press, pp 221 223.

McLauchlin J. Audurier A. Taylor A G 1986 The evaluation of a phage-typing system for Listeria monocytogenes for use in epidemiological studies. Joumal of Medical Microbiology 22:357 365

Mencikova E 1956 Adnátni listeriosy. Ceskoslovenska Epidemiologie, Mikrobiologie, Immunologie 5:225- 228.

Murray E G D, Webb R A, Swann M B R 1926 A disease of rabbits characterised by a large mononuclear leucocytosis, caused by a hitherto undescribed bacillus Bacterium monocrtogenes (n.sp.). Journal of Pathology and Bacteriology 29: 407.439

Myers J P. Peterson G, Rashid A 1983 Peritonitis due to Listeria monocyogenes complicating continuous ambulatory peritoneal dialysis. Journal of Infectious Diseases 148: 1130.

Newman J H, Waycott S, Cooney L M 1979 Arthritis due to Listeria monocytogenes. Arthritis and Rheumatism 22:1139. 1140.

Nieman R E, Lorber B 1980 Listeriosis in adults: a changing 
pattern. Report of eight cases and review of the literature, 1968-1978. Reviews of Infectious Diseases 2:207-227.

Ortel S 1968 Bakteriologische serologische und epidemiologische Untersuchungen wärhrend einer Listerios-Epidemie. Deutsche Gesundheitswesen 23:753-759.

Owen C R, Meis A, Jackson J W, Stoenner H G 1960 A case of primary cutaneous listeriosis. New England Journal of Medicine 262:1026-1028.

Parker M T 1979 Infections with group B streptococci. Journal of Antimicrobial Chemotherapy. 5(Suppl A):27-37.

Pollock S S, Pollock T M, Harrison M J G 1984 Infection of the central nervous system by Listeria monocytogenes: a review of 54 adult and juvenile cases. Quarterly Journal of Medicine 53:331-340.

Ralovich B 1984 Listeriosis research: present situation and perspective. Akadémiai Kiadó, Budapest.

Read E J et al. 1985 Listeria monocytogenes sepsis and small cell carcinoma of the rectum: an unusual presentation of the acquired immunodeficiency syndrome. American Journal of Clinical Pathology 83:385-389.

Real F X, Gold J W M, Krown S E, Armstrong D 1984 Listeria monocytogenes bacteraemia in the acquired immunodeficiency syndrome. Annals of Internal Medicine 101:883-884.

Rocourt J, Schrettenbrunner A, Seeliger H P R 1983 Differenciation biochimique des groupes génomiques de Listeria monocytogenes (sensu lato). Annales de Microbiologie (Institut Pasteur) 134A:65-71.

Schlech W F et al. 1983 Epidemic listeriosis: evidence for transmission by food. New England Journal of Medicine 308: 203-206.

Seeliger H P R 1961 Listeriosis. 2nd edn. Karger, Basel.

Seeliger H P R 1972 New outlook on the epidemiology and epizoology of listeriosis. Acta Microbiologica Academia Scientarum Hungaricae 19:273-286.

Seeliger H P R, Emmerling P, Emmerling H 1969 Listeriosis in Germany. German Medical Monthly XIV:157-163.
Seeliger H P R, Höhne K 1979 Serotyping of Listeria monocytogenes and related species. In: Bergan T, Norris $\mathrm{J}$ R (eds) Methods in Microbiology 13: Academic Press, New York, pp 31-49.

Seeliger H P R, Finger J 1983 Listeriosis. In: Remington J S, Klein J O (eds) Infectious diseases of the fetus and newborn infant. 2nd edn. W B Saunders, Philadelphia, pp 264-289.

Shahamat M, Seaman A, Woodbine M 1980 Influence of sodium chloride, $p \mathrm{H}$ and temperature on the inhibitory activity of sodium nitrite on Listeria monocytogenes. In: Gould G W, Corry J E L (eds) Microbial growth and survival in extremes of environment. Academic Press, London, pp 227-237.

Sinha S K, Jones D, Audurier A, Taylor A G 1983 Perinatal listeriosis and hospital cross infection. Archives of Disease in Childhood 58:938-939.

Skamene E 1983 Genetic regulation of host resistance to bacterial infection. Reviews of Infectious Diseases 5(Suppl 4): S823-S832.

Taylor A G, McLauchlin J, Green H T, Macaulay M B, Audurier A 1981 Hospital cross-infection with Listeria monocytogenes c Jnfirmed by phage-typing. Lancet 2:1106.

Toaff R, Krochik N, Rabinovitz M 1962 Genital listeriosis in the male. Lancet 2:482-483.

Van Eden W, de Vries R R P, Stanford J L, Rook G A W 1983 HLA-DR 3 associated genetic control of response to multiple skin tests with new tuberculins. Clinical and Experimental Immunology 52:287-292.

Veterinary Record (editorial) 1983 Listeria infections in farm animals. Veterinary Record 112:314.

Wetli C V, Roldan E O, Fojaco R M 1983 Listeriosis as a cause of maternal death: an obstetric complication of the acquired immunodeficiency syndrome (AIDS). American Journal of Obstetrics and Gynecology 147:7-9.

Yu V L, Miller W P, Wing E J, Romano J M, Ruiz C A, Bruns F J 1982 Disseminated listeriosis presenting as acute hepatitis. Case reports and review of hepatic involvement in listeriosis. American Journal of Medicine 73:773-777. 